\title{
Investigation and monitoring of tetracycline and degradation products in waters of trout farm
}

\author{
Alabalık çiftliği sularında tetrasiklin ve parçalanma ürünlerinin \\ araştırılması ve izlenmesi
}

\author{
Murat TOPAL 1 \\ ${ }^{1}$ Munzur Üniversitesi, Mühendislik Fakültesi, Çevre Mühendisliği Bölümü, Tunceli, Türkiye. \\ murattopal@munzur.edu.tr
}

Received/Geliș Tarihi: 09.01.2016, Accepted/Kabul Tarihi: 19.04.2016

* Corresponding author/Yazıșilan Yazar

doi: $10.5505 /$ pajes.2016.46704 Research Article/Araștırma Makalesi

\section{Abstract}

In this study, tetracycline and degradation products were determined in the basins of a trout farm and in the stream carrying the waters of trout farm. Tetracycline (TC), 4-epitetracycline (ETC), 4-epianhydrotetracycline (EATC) and anhydrotetracycline (ATC) concentrations were determined under the detection limit in upstream of trout farm. The highest and lowest tetracycline concentrations detected in trout farm are $7.64 \pm 0.38 \mathrm{ppb}$ and under detection limit, respectively. The highest and lowest 4-epitetracycline concentrations were $16.2 \pm 0.8$ and $1.85 \pm 0.09 \mathrm{ppb}$, respectively while the highest and lowest 4-epianhydrotetracycline concentrations detected in trout farm were $25.8 \pm 1.3$ and $6.12 \pm 0.30 \mathrm{ppb}$, respectively. The highest and lowest anhydrotetracycline concentrations detected in trout farm were $18.5 \pm 0.9$ and $6.24 \pm 0.31 \mathrm{ppb}$, respectively. Mean tetracycline, 4-epitetracycline, 4-epianhydrotetracycline and anhydrotetracycline concentrations were $3.52 \pm 0.17 ; 5.30 \pm 0.26 ; 14.4 \pm 0.7$ and $9.64 \pm 0.48 p p b$ in downstream of trout farm. When upstream and downstream were compared in terms of tetracycline and degradation products it could be said that Keban stream was affected as a result of activity of trout farm.

Keywords: Tetracycline, Degradation products, Trout farm, Stream, Turkey

\section{Introduction}

Aquaculture is an alternative to extractive fishing [1],[2]. The demand for aquaculture products is increasing worldwide [3],[4]. Aquaculture is the fastest growing animal food-producing sector [5],[6].

The risk of bacterial infections among aquacultured fish is high [6] as a result of the non-hygienic and stressful conditions [7],[8] present in aquaculture facilities. Diseases in an aquaculture setting are important limiting factor to production and trade. In aquaculture situations, antibiotic are added directly into the water or as a part of the feed [9],[10]. Antibiotics may not be used in a responsible manner in aquaculture [6],[11].

Antibiotics kill the microorganisms or inhibit the growth of them [12]. A class of antibiotics, tetracyclines (TCs), are characterized by a broad spectrum of activity, a relatively high degree of safety, low production and sales costs [13]. A survey on the use of chemotherapeutics in European Union identified TCs as one of the most used antibiotics in fish farming [14]. Also, TCs are commonly used to mark fish. Because they have capacity to fluoresce [15]. TCs are used in microbial control
Öz

Bu çalıșmada, tetrasiklin ve parçalanma ürünleri bir alabalık çiftliğinin havuzlarında ve alabalık çiftliğinin suların tașıan derede tespit edilmistir. Tetrasiklin (TC), 4-epitetrasiklin (ETC), 4-epianhidrotetrasiklin (EATC) ve anhidrotetrasiklin (ATC) konsantrasyonları alabalık çiftliğinin yukarısındaki derede dedeksiyon limitinin altında tespit edilmiștir. Alabalık çiftliğinde tespit edilen en yüksek ve en düşük tetrasiklin konsantrasyonları sırasılyla, $7.64 \pm 0.38$ ppb ve dedeksiyon limitinin altındadır. Alabalık çiftliğinde tespit edilen en yüksek ve en düşük 4-epitetrasiklin konsantrasyonları sırasıyla, $16.2 \pm 0.8$ ve $1.85 \pm 0.09$ ppb iken en yüksek ve en düșük 4-epianhidrotetrasiklin konsantrasyonlarl sirasiyla $25.8 \pm 1.3$ ve $6.12 \pm 0.30$ ppb olmuștur. Alabalık çiftliğinde tespit edilen en yüksek ve en düsük anhidrotetrasiklin konsantrasyonları sirasiyla, 18.5 \pm 0.9 and $6.24 \pm 0.31$ ppb olmuştur. Alabalık çiftliğinin aşağısındaki derede ortalama tetrasiklin, 4-epitetrasiklin, 4-epianhidrotetrasiklin ve anhidrotetrasiklin konsantrasyonları $3.52 \pm 0.17 ; 5.30 \pm 0.26 ; 14.4 \pm 0.7 v e$ $9.64 \pm 0.48$ ppb olmuștur. Alabalık çiftliğinin yukarısında ve așağısında bulunan dere tetrasiklin ve parçalanma ürünleri bakımından mukayese edildiğinde Keban Deresinin alabalı çiftliğinin faaliyetinden etkilendiği söylenebilir.

Anahtar kelimeler: Tetrasiklin, Parçalanma ürünleri, Alabalık çiftliği, Nehir, Türkiye

during the processes of creation and management of fish because of their low cost and easy accessibility [2],[16]. Since the Food and Drug Administration approved the use of oxytetracycline for humans and aquatic animals, the use of TC for the treatment of diseases in aquatic farms has increased [17]-[20].

One of the important source of drugs in the environment is fish farming. It has been estimated that around $70 \%$ of the drugs administrated is released into the environment [21],[22]. The heavy use of antibiotics in aquaculture has resulted in the increase of resistant strains [6],[23]. Widespread use of TCs has resulted in selection for resistant bacteria, and its imprudent use has caused a high prevalence of TC resistance [24]-[27].

Freshwater aquacultural fishering increased in recent years through the new opened dams in Turkey. Turkey ranks third in fish producing in Europe. Turkey produces annually 200.000 tons of trout and most of these are exported. Republic of Turkey Ministry of Food, Agriculture and Livestock gives subsidy support of 65 piaster-1 Turkish Lira per $\mathrm{kg}$ and $50 \%$ equipment. One of the cities those the investments escalate is Elazığ. Fish is one of the rare food product that Turkey exported to the European Nation. Turkey is the leader of Europe in fish 
export. Fume, fresh and cooled trouts are especially exported to the countries of Germany, Holland, Austria, Polland, Romania [28]. Unfortunately, there is not any environmental legislation for the effluents of fish farms in Turkey.

To the best of our knowledge, there is not any study about the concentrations of TC and degradation products (DPs) in a trout farm in Turkey, although a large number of fish farms exist in the country. Because of this, determination of the occurrence and concentrations of antibiotic in fish farms, especially TC and DPs which is known to be one of the most common antibiotics used in fish farming would be worthwhile in order to understand the fate of them in a fish farm. The focus of this study was thus both to investigate the occurrence and concentrations of TC and DPs in a trout farm located in Turkey and the stream carrying the waters of the farm.

\section{Materials and methods}

\subsection{Study area}

The selected study area includes a trout farm and a stream (Keban Stream). It is one of the biggest trout farms in Turkey. Keban Stream is a stream that has continuous flow in all seasons. Keban Stream flows to Firat River that located in downstream of Keban Dam Lake. Firat River is an internationally important river. In the study, Keban Stream is evaluated as two different water bodies because of the aim of the determination of the effect of trout farm on receiving surface water. Upstream of trout farm was referred as water body 1 while downstream of trout farm was referred as water body 2 . Water body 1 was selected as referance point in the study because there was not any trout farm. It is worth to noting that domestic wastewater discharge to the any point of the stream that could affect the concentration of the target pollutant. (Figure 1).

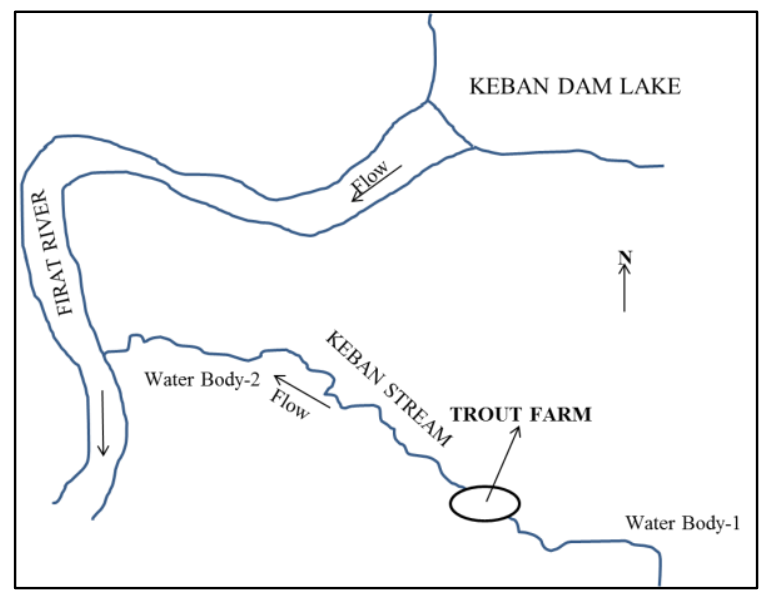

Figure 1: Study area.

\subsection{Chemicals}

TC, 4-epitetracycline (ETC), 4-epianhydrotetracycline (EATC) and anhydrotetracycline (ATC) were analyzed. Oasis HLB $\left(500 \mathrm{mg}, 6 \mathrm{~cm}^{3}\right)$ and OasisMAX $\left(60 \mathrm{mg}, 3 \mathrm{~cm}^{3}\right)$ which purchased from Waters Corporation, Milford, MA, USA were used as cartridges.

\subsection{Sample Collection}

All samples were taken during eight consecutive weeks in summer. Surface water samples were taken from 9 different points; one of them from Keban Stream (upstream of discharge of trout farm waters), seven of them from different points of the trout farm and one of them from Keban Stream (downstream of discharge of trout farm waters). TC and DPs were under detection limit (UDL) in the surface water samples taken from Keban stream (upstream of discharge of trout farm waters). Sampling points of the trout farm are referred as follows;

Sampling point 1 (SP-1): basin of trout sale,

Sampling point 2 (SP-2): the other basin of trout sale,

Sampling point 3 (SP-3): basin of juveniles,

Sampling point 4 (SP-4): basin of trouts,

Sampling point 5 (SP-5): hatchery,

Sampling point 6 (SP-6): basin of fry trouts,

Sampling point 7 (SP-7): basin of broodstock.

Grab samples of surface water were taken from nine different points at each sampling point. Then the nine samples taken were mixed to obtain a homogenious sample from every sampling point. Sample volume was $500 \mathrm{~mL}$. Samples were immediately transported to the laboratory and analyzed.

\subsection{Sample extraction}

Extraction of the samples was done according to the procedure of Jia et al. [29]. The samples were passed from SPE process for the determination of TC and DPs. Oasis HLB and Oasis MAX cartridges were used in SPE process. Oasis HLB cartridges were preconditioned with methylene chloride, methanol and ultrapure water containing $0.5 \mathrm{~g} / \mathrm{L} \mathrm{Na} 2$ EDTA. The samples were passed through the Oasis HLB cartridges. The HLB cartridges were rinsed with ultrapure water. They were dried under a flow of nitrogen and eluted with $6 \mathrm{~mL}$ of methanol. The eluates were collected in an amber vial and dried under a gentle flow of nitrogen. They were reconstituted to $0.3 \mathrm{~mL}$ with methanol. The extracts were diluted to $8 \mathrm{~mL}$ by ultrapure water (adjusted to $\mathrm{pH} 7.0$ with $5 \% \mathrm{NH}_{3} \cdot \mathrm{H}_{2} \mathrm{O}$ ). The solutions were then applied to the Oasis MAX cartridges (preconditioned with methanol, $5 \mathrm{~N}$ $\mathrm{NaOH}$, and ultrapure water). The cartridges were rinsed with $5 \% \mathrm{NH}_{3} \cdot \mathrm{H}_{2} \mathrm{O}$, followed by methanol. Elution was performed with $3 \mathrm{~mL}$ of acetonitrile/water containing 1\% formic acid $(50 / 50, v / v)$ mixed reagents. The extracts were concentrated to $1.5 \mathrm{~mL}$ under a stream of nitrogen. Extracts were measured with ultra fast liquid chromatography-tandem mass spectrometry (UFLC-MS/MS).

\section{$2.5 \quad$ UFLC-MS/MS}

TC and DPs were analyzed using UFLC-MS/MS (Shimadzu Prominence UFLC coupled to 3200 Qtrap, Applied Biosystems). The brief description of the injection volume, mobile phase and gradient is given in Topal et al. [30].

LOD (limit of detection) and LOQ (limit of quantification) of TC and degradation products were calculated. LOD values calculated for TC, ETC, EATC and ATC were 0.307, 0.333, 0.479 and $0.733 \mathrm{ppb}$, respectively while LOQ values were 0.930 , $1.009,1.452$ and $2.220 \mathrm{ppb}$, respectively [31].

\subsection{Statistical analyses}

Statistical studies were done using the IBM SPSS Statistics 21 programme (USA) $(n=3)$.

\section{Results and discussion}

TC and DPs in water samples taken from different points of trout farm are given in Figure 2. 

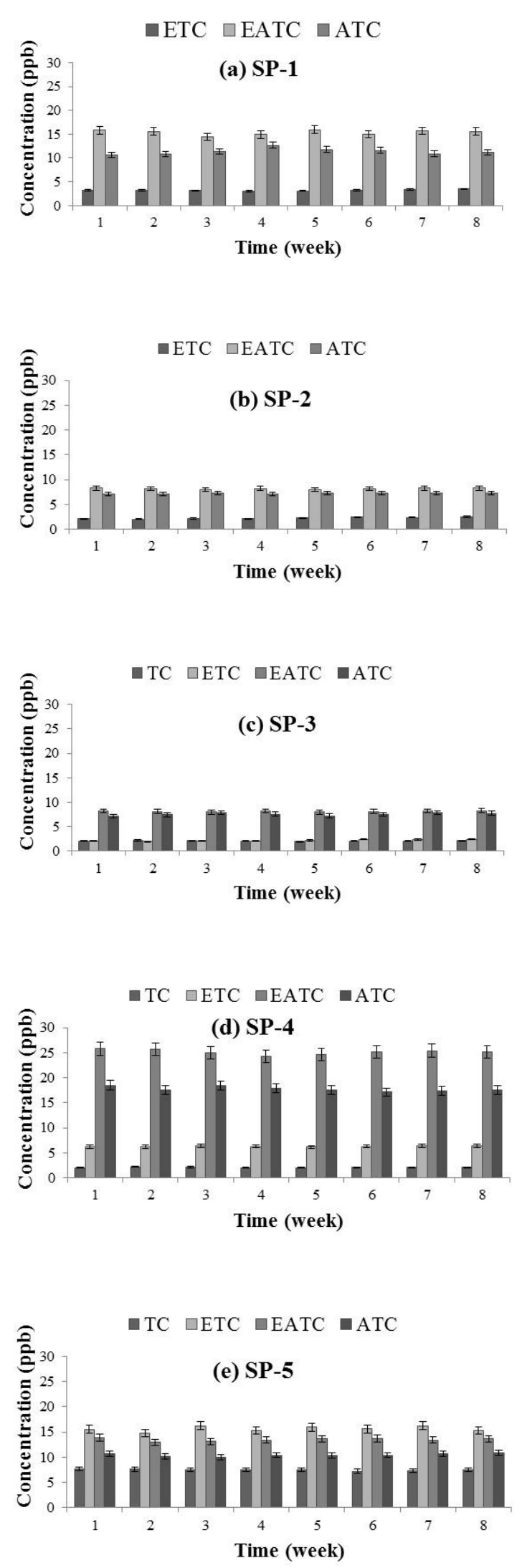
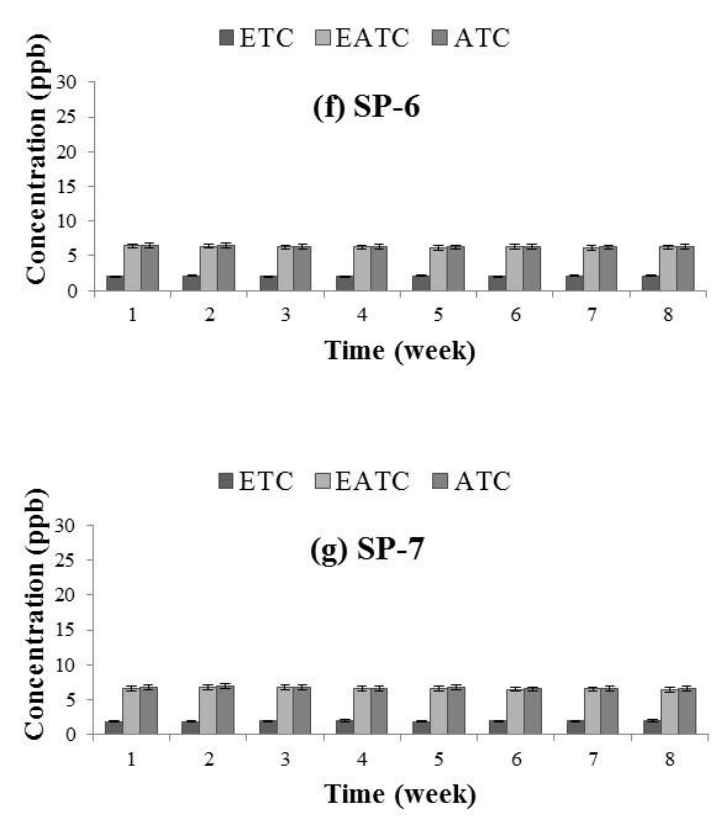

Figure 2. Concentrations of TC and DPs in water samples.

TC concentrations were between $2.0 \pm 0.1$ and $2.21 \pm 0.11 \mathrm{ppb}$ at sampling point 3 (Figure $2 \mathrm{c}$ ) which the juveniles grown while TC concentrations were between $1.96 \pm 0.1$ and $2.14 \pm 0.1 \mathrm{ppb}$ at sampling point 4 (trout basin) (Figure $2 \mathrm{~d}$ ). TC concentrations were between $7.21 \pm 0.36$ and $7.64 \pm 0.38 \mathrm{ppb}$ at sampling point 5 (hatchery) (Figure 2e). TC concentration was under the detection limit in surface water of Keban Stream that was selected as referance point (upstream of trout farm wastewater discharge referred as water body 1). Mean TC concentration was $3.52 \pm 0.17 \mathrm{ppb}$ in surface water of Keban Stream (downstream of trout farm referred as water body 2). When water body 1 and water body 2 were compared in terms of TC it could be said that Keban Stream was affected as a result of activity of trout farm.

TCs are very unstable and decomposed rapidly under the influence of light and atmospheric oxygen, forming more than fourteen different DPs (e.g. the epi- and anhydro-compounds) [32],[33]. Therefore, DPs were also investigated in the present study.

As seen from Figure 2, the highest ETC concentration detected in trout farm was $16.2 \pm 0.8 \mathrm{ppb}$ in weeks 3 and 7 (SP-5) while the lowest ETC concentration was $1.85 \pm 0.09$ ppb in week 1 (SP-7). The situation could probably caused by the transformation of TC to the degradation products and/or transformation of degradation products to each other. This situation is viable for the other degradation products. As reported by Halling-Sorensen et al. [34], TCs are known to possess limited stability in aqueous media. Also, as reported by Brain et al. [35], abiotic degradation products or reversible epimers may be formed through hydrolosis or photolysis, including epi-TCs and anhydro-TCs. ETC concentrations were under detection limit in surface water samples taken from Keban Stream at upstream of trout farm (referance point, water body 1). Mean ETC concentration was $5.30 \pm 0.26 \mathrm{ppb}$ in surface water samples taken from Keban Stream at downstream of trout farm (water body 2). 
Concentration of EATC was maximum $(25.8 \pm 1.3 \mathrm{ppb})$ at SP-4 in week 1 while EATC concentration was minimum $(6.12 \pm 0.30 \mathrm{ppb})$ at SP-6 in week 7 (Figure 2). EATC concentration was under detection limit in the surface water samples taken from Keban Stream at upstream of trout farm (referance point, water body 1). Mean concentration of EATC was $14.4+0.7 \mathrm{ppb}$ in the surface water sample taken from Keban Stream referred as water body 2 (downstream of trout farm).

The highest ATC concentration detected was $18.5 \pm 0.9 \mathrm{ppb}$ in week 1 (SP-4). The lowest ATC concentration detected was $6.24 \pm 0.31 \mathrm{ppb}$ in weeks 5 and 7 (SP-6) (Figure 2). ATC concentration was detected under detection limit in surface water samples taken from Keban Stream at upstream of trout farm (water body 1, referance point) while mean ATC concentration was detected as $9.64 \pm 0.48 \mathrm{ppb}$ in surface water samples taken from Keban Stream at downstream of trout farm (water body 2).

According to Figure 2, the highest concentration in SP-1 and SP2 was obtained for EATC. The decreasing order of TC and DPs was EATC $>$ ATC $>$ ETC. The highest EATC concentrations in SP-1 and SP-2 were $15.9 \pm 0.8$ and $8.27 \pm 0.41 \mathrm{ppb}$, in week 5 and 8 respectively. The highest concentration in SP-3 and SP-4 was obtained for EATC, similar to SP-1 and SP-2. The highest EATC concentrations in SP-3 and SP-4 were $8.27 \pm 0.41$ and $25.8 \pm 1.3$ ppb, in week 8 and 1 respectively and the decreasing order of TC and DPs was EATC $>$ ATC $>$ ETC $>$ TC. The highest concentration $(16.2 \pm 0.8 \mathrm{ppb})$ in SP5 was obtained for ETC in week 3 and 7. The decreasing order was ETC $>$ EATC $>$ ATC $>$ TC. The highest concentration in SP-6 and SP-7 was obtained for ATC. ATC concentrations were $6.52 \pm 0.32$ and $6.88 \pm 0.34 \mathrm{ppb}$, in week 1 and 2 respectively and the decreasing order was ATC $>$ EATC $>$ ETC.

Comparision of TC concentrations determined in sampling points is given in Figure 3.

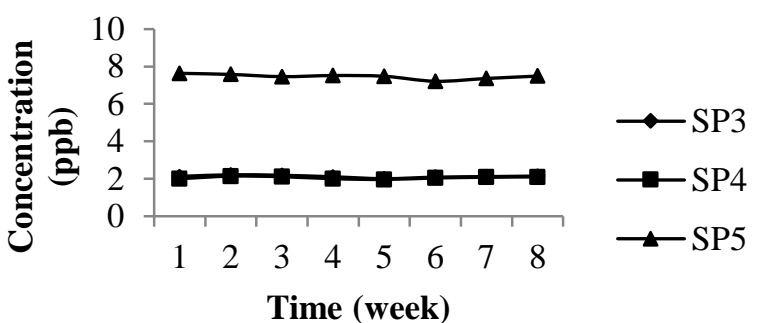

Figure 3. Comparision of TC concentrations determined in sampling points.

There was not any TC at SP-1 and SP-2 those the sale of the trouts are made. Also, it was determined that there was not any TC at sampling points of juveniles and broodstock basins (SP-6 and SP-7). The highest total concentrations (SP-3+SP-4+SP-5) of TC during sampling period was determined in week 2 as $11.93 \pm 0.59 \mathrm{ppb}$. The order of concentrations of TC at sampling points was SP-5>SP-3>SP-4.

Comparision of ETC concentrations determined in sampling points is given in Figure 4.

The highest total concentrations (SP-1+SP-2+SP-3+SP-4+SP$5+$ SP-6+SP-7) of ETC during sampling period was determined in week 7 as $34.86 \pm 1.74 \mathrm{ppb}$. Concentrations of ETC determined at sampling points decreased in the order of SP$5>$ SP-4>SP-3>SP-1>SP-6>SP-2>SP-7.

Comparision of EATC concentrations determined in sampling points is given in Figure 5.

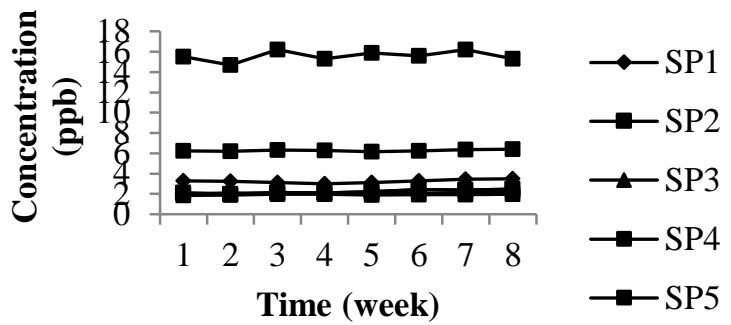

Figure 4: Comparision of ETC concentrations determined in sampling points.

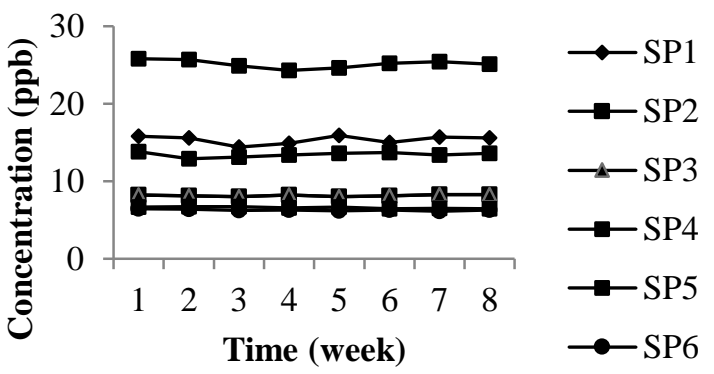

Figure 5: Comparision of EATC concentrations determined in sampling points.

The highest total concentrations $(\mathrm{SP}-1+\mathrm{SP}-2+\mathrm{SP}-3+\mathrm{SP}-4+\mathrm{SP}-$ $5+$ SP-6+SP-7) of EATC during sampling period was determined in week 1 as $84.99 \pm 4.25 \mathrm{ppb}$. The decreasing order of EATC concentrations in sampling points was SP-4>SP-3 $>$ SP-1 $>$ SP5>SP-2>SP-7>SP-6.

Comparision of ATC concentrations determined in sampling points is given in Figure 6.

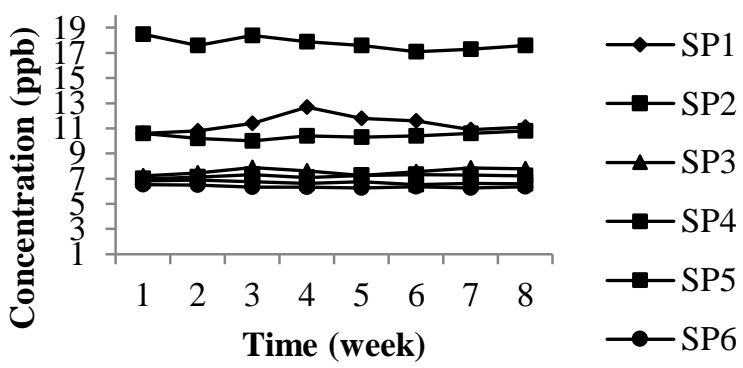

Figure 6: Comparision of ATC concentrations determined in sampling points.

The highest total concentrations (SP-1+SP-2+SP-3+SP-4+SP$5+$ SP-6+SP-7) of ATC during sampling period was determined in week 4 as $68.62 \pm 3.43 \mathrm{ppb}$. ATC concentrations in sampling points followed the order of SP-4>SP-3>SP-1>SP-5>SP-2>SP7>SP-6.

\section{Conclusions}

Elazığ has a big potential for the aquaculture production, especially trout production, due to its number of streams, 
rivers, lakes and dams. With the spread of fishing in dams and rivers the production of trout is increasing day by day in the city. TC and DPs detected in the different sampling points of the trout farm generally followed the order of EATC $>$ ATC $>$ ETC $>$ TC. In terms of TC and DPs, when upstream and downstream of the trout farm were compared, it could be said that Keban Stream was effected as a result of activity of trout farm.

\section{References}

[1] Ostrensky A, Borghetti JR, Soto D. "Aquicultura no Brasil: O Desafio é Crescer Secretaria Especial de Aquicultura e Pesca". Brasília, DF, Brasil, 276, 2008.

[2] Adilson Orlando E, Simionato AVC. "Extraction of tetracyclinic antibiotic residues from fish filet: Comparison and optimization of different procedures using liquid chromatography with fluorescence detection". Journal of Chromatography A, 1307, 111-118, 2013.

[3] FAO. The state of world fisheries and aquaculture 2006. Food and Agriculture Organization Fisheries and Aquaculture Department, Rome, Italy, 2007.

[4] Sindilariu PD, Wolter C, Reiter R. "Constructed wetlands as a treatment method for effluents from intensive trout farms". Aquaculture, 277(3-4), 179-184, 2008.

[5] FAO. "The State of World Fisheries and Aquaculture 2008". Food and Agriculture Organization Fisheries and Aquaculture Department, Rome, Italy, 2009.

[6] Ryu SH, Park SG, Choi SM, Hwang YO, Ham HJ, Kim SU, Lee YK, Kim MS, Park GY, Kim KS, Chae YZ. "Antimicrobial resistance and resistance genes in Escherichia coli strains isolated from commercial fish and seafood". International Journal of Food Microbiology, 152 (1-2), 14-18, 2012.

[7] Barton BA, Iwama GK. "Physiological changes in fish from stress in aquaculture with emphasis on the response and effects of corticosteroids". Annual Review of Fish Diseases, 1, 3-26, 1991.

[8] Sapkota A, Sapkota AR, Kucharski M, Burke J, McKenzie S, Walker P, Lawrence R. "Aquaculture practices and potential human health risks: Current knowledge and future priorities". Environment International, 34(8), 1215-1226, 2008.

[9] Harper C. "Chemical resistance of pathogens in aquaculture". Aquaculture Magazine, 28, 51-52, 2002.

[10] Jacobs L, Chenia HY. "Characterization of integrons and tetracycline resistance determinants in Aeromonas spp. isolated from South African aquaculture systems". International Journal of Food Microbiology, 114(3), 295-306, 2007.

[11] Grigorakis K, Rigos G. "Aquaculture effects on environmental and public welfare-the case of Mediterranean mariculture". Chemosphere, 85(6), 899-919, 2011.

[12] Cháfer-Pericás C, Maquieira A, Puchades R, Miralles J, Moreno A. "Multiresidue determination of antibiotics in feed and fish samples for food safety evaluation. Comparison of immunoassay vs LC/MS-MS". Food Control, 22(6), 993-999, 2011.

[13] Harnisz M, Gołaś I, Pietruk M. “Tetracycline-resistant bacteria as indicators of antimicrobial resistance in protected waters-the example of the Drwęca River Nature Reserve (Poland)". Ecological Indicators, 11(2), 663-668, 2011.
[14] Kowalski P. "Capillary electrophoretic method for the simultaneous determination of tetracycline residues in fish samples". Journal of Pharmaceutical and Biomedical Analysis, 47(3), 487-493, 2008.

[15] MacFarlane AJ, Sutherland DL, Goff TR, Gilmour KM. "In vivo photostabilization of tetracycline hydrochloride by reduced glutathione for use as an ecological marker in Salmo salar". Aquaculture, 213(1-4), 253-263, 2002.

[16] Paschoal JAR. "Thesis Resíduos de Antimicrobianos em Peixe: Depleção Residual e Desenvolvimento de Métodos PhD Thesis, Analíticos Universidade Estadual de Campinas". Campinas, Spain, 2007.

[17] DePaola A, Flynn PA, McPhearson RM, Levy SB. "Phenotypic and genotypic characterization of tetracycline- and oxytetracycline-resistant Aeromonas hydrophila from cultured channel catfish (Ictalurus punctatus) and their environments Applied and Environmental Microbiology, 54(7), 1861-1863, 1988.

[18] Schmidt AS, Bruun MS, Dalsgaard I, Larsen JL. "Incidence, distribution, and spread of tetracycline resistance determinants and integron-associated antibiotic resistance genes among motile aeromonads from a fish farming environment". Applied and Environmental Microbiology, 67(12), 5675-5682, 2001.

[19] Miranda CD, Kehrenberg C, Ulep C, Schwarz S, Roberts MC. "Diversity of tetracycline resistance genes in bacteria from Chilean salmon farms". Antimicrobial Agents and Chemotherapy, 47(3), 883-888, 2003.

[20] Jun LJ, Jeong JB, Huh MD, Chung JK, Choi DL, Lee CH, Jeong HD. "Detection of tetracycline-resistance determinants by multiplex polymerase chain reaction in Edwardsiella tarda isolated from fish farms in Korea". Aquaculture, 240(1-4), 89-100, 2004.

[21] Jacobsen P. "Lasse Berglind stence of oxytetracycline in sediments from fish farms". Aquaculture, 70(4), 365-370, 1988.

[22] Díaz-Cruz MS, López de Alda MJ, Barceló D. "Environmental behavior and analysis of veterinary and human drugs in soils, sediments and sludge". Trends in Analytical Chemistry, 22(6), 340-351, 2003.

[23] Smith P, Hiney MP, Samuelsen OB. "Bacterial resistance to antimicrobial agents used in fish farming: a critical evaluation of method and meaning". Review of Fish Diseases, 4, 273-313, 2003.

[24] Roberts MC. "Tetracycline resistance determinants: mechanisms of action, regulation of expression, genetic mobility, and distribution". FEMS Microbiology Reviews, 19(1), 1-24, 1996.

[25] Chopra I, Roberts M. "Tetracycline antibiotics: mode of action, applications, molecular biology, and epidemiology of bacterial resistance". Microbiology and Molecular Biology Reviews, 65(2), 232-260, 2001.

[26] Roberts MC. "Tetracycline therapy: Update". Clinical Infectious Diseases, 36(4), 462-467, 2003.

[27] Koo HJ, Woo GJ. "Distribution and transferability of tetracycline resistance determinants in Escherichia coli isolated from meat and meat products". International Journal of Food Microbiology, 145 (2-3), 407-413, 2011.

[28] Özgentürk J. "Trout Shock to Turkey". http://www.hurriyet.com.tr/ekonomi/27436924.asp (23.10.2014). 
[29] Jia A, Xiao Y, Hu J, Asami M, Kunikane S. "Simultaneous determination of tetracyclines and their degradation products in environmental waters by liquid chromatography-electrospray tandem mass spectrometry". Journal Chromatography A, 1216(22), 4655-4662, 2009.

[30] Topal M, Uslu Şenel G, Öbek E, Arslan Topal EI. "Bioaccumulation of tetracycline and degradation products in Lemna gibba L. exposed to secondary effluents". Desalination and Water Treatment, 57(18), 8270-8277.

[31] Topal M. "Uptake of tetracycline and degradation products by Phragmites australis grown in stream carrying secondary effluent". Ecological Engineering, 79, 80-85, 2015.

[32] Liang Y, Denton MB, Bates RB. "Stability studies of tetracycline in methanol solution". Journal of Chromatography A, 827 (1), 45-55, 1998.
[33] Liu Y, Yang H, Yang S, Hu Q, Cheng H, Liu H, Qiu Y. "Highperformance liquid chromatography using pressurized liquid extraction for the determination of seven tetracyclines in egg, fish and shrimp". Journal of Chromatography B, 917-918, 11-17, 2013.

[34] Halling Sørensen B, Sengelov G, Tjornelund J. “Toxicity of tetracyclines and tetracycline degradation products to environmentally relevant bacteria, including selected tetracycline-resistant bacteria". Archives of Environmental Contamination and Toxicology, 42(3), 263-271, 2002.

[35] Brain RA, Wilson CJ, Johnson DJ, Sanderson H, Bestari K, Hanson ML, Sibley PK, Solomon KR. "Effects of a mixture of tetracyclines to Lemna gibba and Myriophyllum sibiricum evaluated in aquatic microcosms". Environmental Pollution, 138(3), 425-442, 2005. 